Journal of Community Based Environmental Engineering and Management, 2020, Vol. 4, No. 2: 51-56

\title{
SELECTION OF SUSTAINABLE DOMESTIC WASTE MANAGEMENT TECHNOLOGY CASE STUDY: TANJUNG MEKAR VILLAGE, KARAWANG
}

\author{
Nadia Paramita*, Sari Sekar Ningrum \\ Department of Environmental Engineering, Binawan University
}

\begin{abstract}
The Citarum River is one of the rivers that is a source of clean water and is consumed by residents in the watershed and in DKI Jakarta. Currently, the Citarum River is facing serious environmental problems because it is a reservoir for waste from various sources such as factory, hotel and hospital waste as well as domestic waste, silting, problems with embankments and final treatment sites that are harmful to health. The results of monitoring the water quality of the Citarum River show that the water of the Citarum River has not been able to meet the water quality standards that have been determined based on the SK. West Java Governor No. 39 of 2000. The decline in water quality is caused by an increase in the pollutant load originating from the population, industrial development, extensification and intensification of agricultural land, fisheries development, livestock pollution and mining and excavation exploration. The focus of this research is emphasized on the river pollutant waste management program from domestic waste originating from community activities in Tanjung Mekar Village. The purpose of this study was to analyze waste management systems and domestic wastewater that are easily applied by the community, especially along rivers, in supporting community-based environmental management.
\end{abstract}

Kata kunci: waste, domestic, technology, management, Citarum

\section{Introduction}

The increase in population in cities due to population movement from rural to urban areas can cause various problems. This is due to the disproportionate number of population movements with the amount of land and supporting facilities, which causes dense slum areas such as those on the banks of the Citarum River (Yustiani et.al, 2016).

The water that comes from the Citarum River becomes unsuitable for consumption due to the habit of residents around the Citarum River to throw feces into the river which causes the river water to be full of E.coli bacteria. One example

\footnotetext{
${ }^{*}$ Corresponding Author:

E-mail: nadia@binawan.ac.id

Received:14 August 2020

Revised: 24 August 2020

Accepted: 29 August 2020
}

of the poor quality of Cikapundung water quality test in 2005 shows that the fecal coli level in the Cikapundung River reaches 50,000/ 100 milliliters or 250 times above the quality standard, thousands of residents who consume well water adjacent to the Cikapundung River are prone to various diseases, especially diarrhea (Wibowo, 2007).

The Citarum River is a river that passes through several cities and provinces with a high enough density as residential and industrial areas so that the amount of waste generated is quite large (Yustiani et.al, 2019). This can be seen from the large capacity of waste that is lifted to the TPA every day. In a solid waste system, many related activities are ranging from packaging, transportation and collection to the TPA, so that problems may arise that can reduce the effectiveness of the existing system. The potential for handling waste itself through the 
application of 3R (Reduce, Reuse, Recycle) also needs to be observed so that it can increase its economic value while overcoming the problem of waste quantity. For this reason, it is necessary to carry out observations and research to analyze the waste handling problems in Sekeloa Village and their solutions.

Wastewater originating from industrial activities generally contains a mixture of various organic types. Wastewater treatment to remove dissolved organic materials, nutrients and hardto-settle solids usually use a biological process and if it is done Physico-chemical, it will be quite expensive. One of the most widely used biological treatments is the activated sludge process. The activated sludge process is designed to obtain specific effluent quality while the regulation and control of operational conditions aims to ensure that effluent quality is maintained with minimal operating costs.

The Citarum River is a very vital and strategic river, where $80 \%$ of it is consumed by people in the watershed, so this causes health problems for the community. The most common problem is the presence of waste consisting of waste from factories, hotels and hospitals as well as domestic waste, silting, problems with embankments and final treatment sites that are harmful to health.

The source of the Citarum river pollution consists of 6,543 hectares including critical land due to forest encroachment, $31.4 \%$ erosion in the upstream area of the Citarum, 400 tons of cow dung from 29,000 cows dumped into the Citarum River. Of the 1500 industries that dispose of chemical waste (280 tons/day), it can be seen that $500,000 \mathrm{~m}^{3} /$ year of waste enters the Citarum River (Paramita \& Ningrum, 2020).

The results of monitoring of the water quality of the Citarum River show that the water of the Citarum River has not been able to meet the water quality standards that have been determined based on the SK. West Java
Governor No. 39 of 2000. The decline in water quality is caused by an increase in a load of pollutants originating from the population, industrial development, extensification and intensification of agricultural land, fisheries development, livestock pollution and mining and excavation exploration (Bukit, NT, 2002).

With a fairly heavy load from the conditions of the Citarum River above, comprehensive handling is required from various perspectives and various parties. This will be easily managed if it can be identified and treated according to the sources of pollution. As for the handling of domestic waste, both greywater and black water, it can be overcome by changing the behavior of defecating and small in the river by making communal toilets. Toilets and household wastewater are channeled into communal reservoirs equipped with simple biogasproducing technology so that the residents can use them. Another system that can be applied to individual septic tanks is to use a wetland so that the waste is not directly disposed of into the environment or rivers.

A sanitation system based on its sustainability has several criteria (Winblad, 2004), including:

a. Prevent disease: sanitation systems must be able to destroy or isolate pathogenic microorganisms.

b. Has purchasing power: the sanitation system must be accessible to all levels of society in the world down to the poorest people.

c. Protecting the environment: sanitation systems must prevent pollution, restore soil nutrients and maintain water resources.

d. Acceptable: the sanitation system must maintain aesthetic values and be consistent with the cultural and social values of the community.

e. Simple: the sanitation system must be robust, easily maintained by people with limited technical knowledge, organization and economic resources. 
Domestic wastewater is usually generated from toilets, bathrooms, kitchens and water washing clothes, therefore liquid waste is classified into four which are listed in Table 1.

Table 1. Distribution of Domestic Wastewater (Höglund, 2001)

\begin{tabular}{ccc}
$\begin{array}{c}\text { Types } \\
\text { of } \\
\text { Waste }\end{array}$ & Source & Impact \\
\hline $\begin{array}{c}\text { Yellow } \\
\text { water }\end{array}$ & $\begin{array}{c}\text { Urine } \\
\text { with/without } \\
\text { flushing water }\end{array}$ & $\begin{array}{c}\text { Contains 90\% body } \\
\text { nitrogen, 55\% phosphate, } \\
\text { large amounts of } \\
\text { potassium }\end{array}$ \\
\hline $\begin{array}{c}\text { Brown } \\
\text { water }\end{array}$ & From feces & $\begin{array}{c}\text { Causes disease caused by } \\
\text { organisms present in } \\
\text { feces }\end{array}$ \\
\hline $\begin{array}{c}\text { Black } \\
\text { water }\end{array}$ & $\begin{array}{c}\text { Combination } \\
\text { of urine and } \\
\text { feces }\end{array}$ & $\begin{array}{c}\text { Because it is a } \\
\text { combination of two } \\
\text { sources, it needs serious } \\
\text { handling }\end{array}$ \\
\hline Grey & $\begin{array}{c}\text { From kitchen } \\
\text { activities, } \\
\text { water }\end{array}$ & $\begin{array}{c}\text { The phosphate content of } \\
\text { detergents is quite high, } \\
\text { solids and organic matter } \\
\text { (fat, oil, grass) from food } \\
\text { and cooking are quite } \\
\text { high }\end{array}$ \\
\hline
\end{tabular}

The characteristics of domestic waste are generally almost the same in most homes. On the other hand, industrial wastewater and public facilities have the characteristics of pollutants that are more diverse and in large quantities. Based on the concentration of each component, liquid waste can be classified into three, namely strong, medium and weak. In general, the typical characteristics of domestic wastewater and fecal sludge can be seen in Table 2. The composition of domestic liquid waste is based on the Decree of the Minister of Environment and Forestry No. 68/2016:

Table 2. Domestic wastewater quality standards that can be discharged into water bodies (KepMen LHK No 68 Tahun 2016)

\begin{tabular}{ccc}
\hline Parameter & Unit & $(\mathbf{m g} / \mathbf{l t})$ \\
\hline $\mathrm{pH}$ & - & $6-9$ \\
\hline $\mathrm{BOD}$ & $(\mathrm{mg} / \mathrm{lt})$ & 30 \\
\hline
\end{tabular}

\begin{tabular}{ccc}
\hline Parameter & Unit & ( mg/lt $)$ \\
\hline COD & $(\mathrm{mg} / \mathrm{lt})$ & 100 \\
\hline TSS & $(\mathrm{mg} / \mathrm{lt})$ & 30 \\
\hline Oil dan fat & $(\mathrm{mg} / \mathrm{lt})$ & 5 \\
\hline
\end{tabular}

Based on the Ministry of Environment and Forestry (2016), domestic sources consist of wastewater from flats, inns, dormitories, health services, educational institutions, offices, commerce, markets, restaurants, meeting halls, recreation areas, settlements, industries, WWTP for the area, WWTP for residential areas, WWTP for urban areas, ports, airports, train stations, terminals and correctional facilities.

For domestic liquid waste and feces, the handling is simple by building a septic tank in each housing or communal septic tank in densely populated settlements collectively. For areas that do not have waste treatment, an integrated domestic liquid waste treatment is used.

A centralized treatment system or what is also called a centralized system/off-site system, is a wastewater treatment system from all service areas that is collected through a city sewer to a wastewater treatment plant (WWTP) and/or with a certain dilution (intersepting sewer). Furthermore, if it has met the quality standards it can be discharged to the receiving water body $\mathrm{A}$ centralized system is also called a conventional system, which requires a sewage collection/channeling channel, therefore it requires quite high investment costs as well as large operational and maintenance costs, especially for relatively flat urban areas that require a pumping system. Treatment technologies that are widely used include aquaculture, anaerobic with biogas digester, stabilization ponds, requiring a distribution system such as small bore sewer, shallow bore sewer, conventional sewerage system. In the treatment of WWTP, there are several primary treatments including screen, grit removal, equalization tank, primary sedimentation tank. As for secondary processing technology, 
activated sludge can be used, contact stabilization, aerated lagoon, oxidation ditch, Rotating Biological Contractor (RBC), trickling filter.

The local processing system or also known as a decentralized system/on-site system is a wastewater treatment system, where wastewater is disposed of and treated directly on the spot without going through the first distribution. This system requires specific location technical requirements but the costs are relatively low. This system is mainly intended for areas that do not have real city facilities or for small neighborhoods where land is still available. The technologies used in on-site processing include the use of septic tanks, grease traps, pit latrine, composting, gray waste, beer put (Malisie, 2006).

\section{Research Methodology}

The research focus is emphasized on determining strategies for increasing access to sustainable domestic wastewater service systems in improving domestic wastewater management in densely populated residential areas. The technology selection is based on two local system sanitation approaches, namely individual septic tanks and communal sewage treatment systems.

The survey method used is a descriptive method, which is a research method that is preliminary data extraction to develop strategies and is used to analyze situations with the aim of making descriptions, descriptions systematically, factually and accurately regarding the facts or the relationship between the phenomena under study.

The stages of this research are as follows:

1. The literature study includes the process of reviewing the theory and concept of sustainable sanitation in the treatment of domestic waste in slum settlements and the areas of settlements and housing, especially wastewater management in dense settlements.

2. Analysis of domestic wastewater management is a review of existing wastewater management and improved management that can change the current conditions of wastewater treatment, as well as its management by the Government and community participation.

3. Data collection consists of:

a. Primary data to be collected is in the form of field conditions regarding the existing conditions of the wastewater management system in slum settlements in riverbank areas by:

- Observation in the field as preparation for compiling materials.

- Structured interviews, which are data collection procedures where the interviewer knows exactly what information will be obtained. This requires a research instrument in the form of written questions with alternative answers.

- The questionnaire consists of two types of questionnaires. The first questionnaire to determine densely populated areas. The second questionnaire is aimed at the community, the quality and quantity of facilities and access to domestic wastewater in Cililitan Village. Sampling was done by random sampling. This type of questionnaire is a closed questionnaire.

b. The questionnaire consists of two types of questionnaires. The first questionnaire to determine densely populated areas. The second questionnaire is aimed at the community, the quality and quantity of facilities and access to domestic wastewater in Cililitan Village. Sampling was done by random sampling. This type of questionnaire is a closed questionnaire. 


\section{Result and Discussion}

Based on the results of research conducted on the community in RW 2, Tanjung Mekar Village, Kawarang, from the random sampling that has been done, it is known that these people are in the middle to lower economic strata with an average income below Rp. 1,500,000.

With the average number of residents of 8 people per house, which is $65 \%$, it shows that most of the residents still live together as a big family, not just this family. As for the consumption of clean water they use daily for one family ranges from 40-200 liters/day. The rest only a small portion uses less than 40 liters, namely 5\% and 20\% more than 200 liters/day. $59 \%$ of the residents use clean water from private wells or install a jet pump and $20 \%$ rely on PDAM as a source of clean water for their daily activities.

Regarding the quality of water based on the survey, $65 \%$ of residents in RW 2 did not experience difficulties getting clean water with good water conditions because most of them stated that the water was not cloudy, colored, smelly, or foamy, namely $80 \%$ while the remaining $20 \%$ felt that the water was cloudy, colored and smelly.

For drinking water needs, $76 \%$ still rely on well water which is then boiled and then used as drinking and cooking water. Meanwhile, 14\% use bottled mineral water and only $3 \%$ use filtered water for drinking water.

The results of qualitative analysis related to black water wastewater management show that most residents already have private toilets and toilets, namely $88 \%$, and only $8 \%$ use public bathing, washing, and toilet facilities and the rest are with families. Respondents who use public bathing, washing, and toilet facilities are generally free of charge and only $26 \%$ are charged a fee ranging from Rp. 1,000 - Rp. 2,000 as maintenance costs in certain toilets.
Regarding the domestic wastewater disposal channel, as many as $91 \%$ stated that they have a sewer, but the domestic waste disposal channel uses open sewers/drains and rivers so that basically the domestic waste has not been managed properly and properly. The condition of the channel is $75 \%$ open channel with smooth flow conditions and 25\% through a closed channel with a smooth flow.

Gray water waste or those originating from washing dishes and clothes is shown in Figure 1.

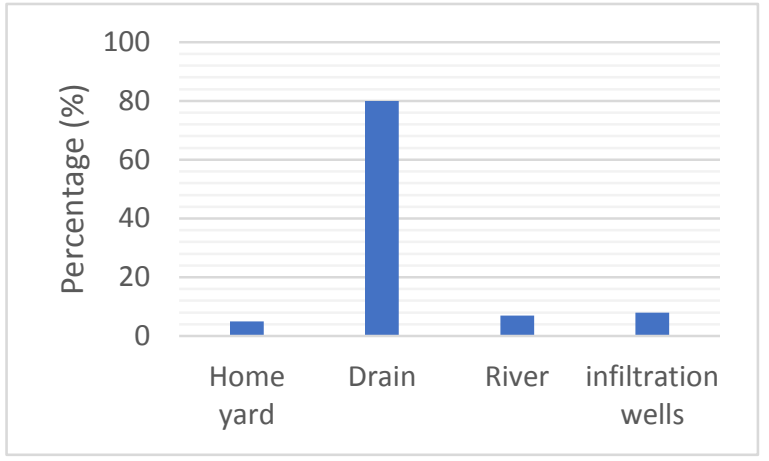

Figure 1. Management of gray water

As many as $80 \%$ of the residents have used septic tanks to collect their black water waste. The use of this septic tank is not yet proportional to the understanding of all users about the obligation to carry out desludging. This is indicated by the low percentage of residents who do suction regularly. $70 \%$ of respondents never do suction, the rest they do suction but very rarely, that is, between 1-2 years as many as $24 \%$ of respondents and the rest admit to doing suction within 1 year.

Regarding the understanding regarding the quality of clean water sources, where the distance of clean water sources, in this case, from private wells, is still very low. The results showed that only $3 \%$ of the respondents met the eligibility criteria for a distance of 10 meters from the clean water source to the septic tank. The large percentage of respondents who built a septic tank close to a well, which is less than 10 meters, shows the low level of public knowledge 
of the importance of maintaining clean water quality. Because the small radius of the distance between the septic tank and the water source will increase the potential for the entry of bacteria, viruses and other pollutants and contaminate water sources.

Based on the conditions above, this shows that domestic waste in the Tanjung Mekar village has not been well managed and has the potential to pollute the environment so that it requires proper management and can be implemented by the community in a sustainable manner in the area.

Regarding the alternative management of domestic waste water, $88 \%$ of respondents are willing to separate feces and urine if there is supporting technology. Biogas-producing waste processing technology that can be used for cooking has a positive response from residents, where $91 \%$ of residents are willing to use it if available. Meanwhile, the technology viewer with the wetland system is only interested in $75 \%$ of the respondents, while the other $25 \%$ are not willing to apply wetland in their homes.

\section{Conclusion}

The conclusion from this research activity is that there are still many residents of Tanjung Mekar Village who directly dispose of their domestic waste into ditches and rivers. This certainly contributes to the increase in the number of soil pollution and pollution of the Ciliwung river.

Domestic waste pollution due to waste that is not properly managed in Tanjung Mekar Village can be prevented by using biogas technology which is expected to be sustainable because it is based on the needs and abilities of its residents.

\section{References}

Bukit, NT \& Yusuf I.A. (2002). Jurnal Teknologi Lingkungan. 3(3) : 98-106.

Höglund, C. (2001). Evaluation of Microbial Health Risks Associated with the Reuse of
Source Separated Human Urine. PhD thesis, Department of Biotechnology, Royal Institute of Technology, Stockholm, Sweden. ISBN 91-7283-0395.

Keputusan Menteri Lingkungan Hidup dan Kehutanan No 68 Tahun 2016 tentang Baku Mutu Air Limbah Domestik.

Malisie, A., Prihandrijanti, M., dan Otterpohl, R. (2006). Cost Benefit Analysis for Centralized and Decentralized Wastewater Treatment System (Case study: Surabaya-Indonesia), Journal of Sustainability and Environmental Safety. http://www.tu-hamburg.de.

Paramita, Nadia \& Sari Sekar Ningrm. (2020). Pengelolaan Lingkungan Sungai Berdasarkan Sumber Pencemaran di Sungai Citarum Studi Kasus Kelurahan Tanjung Mekar. JUARA: Jurnal Wahana Abdimas Sejahtera, 1 (1), 38 - 50.

Wibowo, Juli. (2007). Strategi Peningkatan Sanitasi Lingkungan Permukiman di Bantaran Sungai Kabupaten Hulu Sungai Selatan. Tesis. Institut Teknologi Surabaya

Winblad, U. and Simpson-Hébert, M. (2004) Ecological Sanitation-Revised and Enlarged Edition. Stockholm Environment Institute, Stockholm

Yustiani, Y.M. and Lidya, L. (2016) Towards an Information System of Modeling and Monitor of Cikapundung River, Bandung, Indonesia, Procedia Engineering, 154, pp. 353-360

Yustiani, Y.M., Wahyuni, S., Dewi, S.N.F. (2019) Determination of maximum BOD load using water quality modeling of upstream Citarum River, International Journal of Geomate, Vol. 16, Issue 56, pp.118-122 